\title{
AS CASAS DE ÓPERA E O RIO DE JANEIRO NO SÉCULO XVIII: NOVOS ESPAÇOS DE LIBERDADE
}

OPERA HOUSES AND RIO DE JANEIRO IN THE 18th CENTURY: NEW FREEDOM SPACES

Sergio Moraes Rego Fagerlande Universidade Federal do Rio de Janeiro sfagerlande@gmail.com

\section{Resumo}

O artigo relaciona a formação dos primeiros edifícios teatrais do Rio de Janeiro no século XVIII e as transformações sociais e urbanas daquele período, mostrando a importância desses novos espaços relacionados ao lazer e à cultura em uma sociedade ainda muito ligada à religião. A partir de estudos sobre um dos primeiros teatros, a Casa de Ópera de Manoel Luiz, construída na segunda metade do século e localizada junto ao Palácio dos Vice-Reis, pode se estabelecer um novo modelo de espaço ligado a iniciativas privadas, mas relacionadas ao poder real, influenciando o espaço público e trazendo novas ideias de liberdade para a cidade.

\section{Palavras-chave}

Edifício teatral. Casa de ópera de Manoel Luiz. Teatro Régio. Rio de Janeiro. Espaços públicos. História das cidades.

\begin{abstract}
This article relates the appearance of the first theatre buildings in $18^{\text {th }}$-century Rio de Janeiro to the social and urban changes occurred in that period, showing the importance of these new spaces as related to leisure and culture in a society still deeply rooted in religion. Based on studies of one of the first theatres, the Casa de Ópera de Manoel Luiz [Opera House], built in the second half of the century next to the 'Palácio dos Vice-Reis' [Palace of Viceroys], it is possible to establish a new space model, linked to private enterprises, but related to real power that influence the public space and bring new concepts of freedom to the city.
\end{abstract}

\section{Keywords}

Theatre building. Manoel Luiz opera house. Teatro Régio [Royal Theatre]. Rio de Janeiro. Public spaces. History of the cities.

(c) Urbana: Rev. Eletrônica Cent. Interdiscip. Estud. Cid. Campinas, SP $\quad$ v.10, n.1 [18] p.104-130 jan./mai. 2018 


\section{Introdução}

O artigo busca relacionar a formação dos primeiros edifícios para uso exclusivo como teatros na cidade do Rio de Janeiro no século XVIII e as transformações urbanas e sociais daquele período, mostrando a importância desses novos espaços relacionados ao lazer e à cultura dentro de uma sociedade bastante ligada à religião e que tem nessas casas alguns de seus primeiros espaços laicos, trazendo a liberdade e conceitos de sociedade civil para a cidade. A partir de estudos sobre um dos primeiros teatros da cidade, a Casa de Ópera de Manoel Luiz ${ }^{1}$, construída na segunda metade do século e localizada junto ao Palácio dos ViceReis (FAGERLANDE, 1998, 2012), pode-se estabelecer um novo modelo de espaço ligado a iniciativas privadas, mas relacionadas ao poder real. O estudo buscou na bibliografia da história da cidade e de seus teatros dados para a comprovação da existência e importância desse edifício, que tendo sido criado em torno de 1758 (CAVALCANTI, 2004; BRESCIA, 2010) passou por vários momentos, inclusive se tornando Teatro Régio a partir da chegada da corte em 1808, até seu fechamento em 1813, momento da inauguração de um novo teatro oficial, o Real Teatro São João² (FAGERLANDE, 2007; LIMA, 2000). A existência do edifício até 1910 permitiu que a fotografia, além de grande número de gravuras, registrasse sua aparência externa, a partir da qual foi realizado um estudo hipotético de seu interior, comparando com outros teatros da época ainda existentes, como o de Ouro Preto. A relação com a cidade se complementa não somente com os usos em seu interior, mas também com as novas comemorações ali realizadas, que se estendiam para a praça em sua frente, trazendo para a cidade um novo momento de festas e manifestações ligadas ao que Starobinski (1994) fala ser um momento de invenção da liberdade, em que se criam novas relações civis na sociedade ocidental.

O Rio de Janeiro, fundado em 1565, passara a ser no século XVIII um importante porto do império colonial português. A descoberta do ouro e diamantes acentuara essa importância, o que foi reforçado com a transferência em 1763 da sede do Vice-Reino

\footnotetext{
1 No século XVIII ópera tinha o significado de peça de teatro, mesmo que não fosse cantada (CAVALCANTI, 2004), e de acordo com Dias (2012) chamar de casa de ópera distinguia dos teatros de marionetes populares no momento.

${ }^{2}$ O Real Teatro Sâo João, inaugurado em 1813, passou a se chamar Imperial Teatro de São Pedro de Alcântara em 1824, e depois de muitos incêndios e reconstruções no mesmo local existe atualmente o Teatro João Caetano, na Praça Tiradentes (FAGERLANDE, 2007).
} 
português do Brasil de Salvador para a cidade ${ }^{3}$. Mesmo antes desse evento a cidade vinha sendo palco de diversas intervenções urbanísticas que deram alguma infraestrutura a esse aglomerado urbano. Foram realizadas várias construções importantes para o lazer e bem-estar da população, como chafarizes, cuja alimentação demandou monumental obra de abastecimento de água, destacando-se o Aqueduto da Carioca, inaugurado em 1750, e um parque como o Passeio Público, concluído em 1783 e inaugurado em 1785 (MONTEIRO DE CARVALHO, 1999). No local mais significativo da cidade, o Largo do Carmo, centro de poder do país, onde se localizava o Palácio dos Governadores, existiu a Casa de Ópera, possivelmente inaugurada em 1758 (CAVALCANTI, 2004), em local demonstrado em mapa do período (CUNHA, 1971) ${ }^{4}$. Todas essas obras enunciavam uma nova política por parte dos dirigentes, como reflexo de postura mais liberal e mais preocupada com a população, especialmente a burguesia ascendente (FAGERLANDE, 1998).

Monteiro de Carvalho (1999) fala de como o Rio de Janeiro seguia o modelo que surgia na Europa, onde a partir do crescimento das cidades e de um novo sentido para o que se chamaria "povo", a sociedade se transformava através da razão e da ação, com uma nova lógica de bem-estar, e que isso se refletia nos melhoramentos urbanos. Starobinski (1994) fala do século XVIII como um momento de disputa entre o poder absoluto e as novas possibilidades que o pensamento de autonomia iria trazer para as pessoas, com o nascimento de ideias refletido em uma luta por liberdade, não somente política, mas de liberdades civis.

As obras para o bem-estar da população indicam a existência de um novo olhar para a cidade e suas necessidades, mostrando que essa política de civilidade (MONTEIRO DE CARVALHO, 1999) desenvolvida inicialmente pelas ordens terceiras, ligadas à igreja, mas laicas, seria encampada pelo poder público, através dos vice-reis, seguindo indicações do Marquês de Pombal, que adotou política ao mesmo tempo centralizadora, mas também modernizadora para o reino e suas colônias.

Dentro de um quadro de mudanças urbanas, Pombal fora o responsável pela modernização da cidade de Lisboa após o terremoto de 1755 , e suas ideias passaram a influenciar outras cidades coloniais. Seu projeto incluía um plano de urbanização, que trazia o controle urbano em aspectos como maior aeração, iluminação, higienização, lazer e

${ }^{3}$ O Brasil tornou-se vice-reino em 1640, logo após a restauração do trono português, com a separação do domínio espanhol.

${ }^{4}$ Nomapa de 1758 aparece o nome Ópera, mesmo com a posição errada, no quarteirão ao lado do local correto. 
embelezamento (MONTEIRO DE CARVALHO, 1999). No Rio de Janeiro o responsável por muitas obras ligadas a essas ideias foi dom Luís de Vasconcelos, vice-rei entre 1779 e 1790.

As melhorias implantadas não foram apenas físicas, mas também de incentivo às artes e à cultura, como a criação de Academia Científica pelo vice-rei Marquês do Lavradio, ${ }^{5}$ bastante interessado na coleta e catalogação de plantas e animais nativos. As festas, fossem religiosas ou profanas, eram igualmente estimuladas.

Passando a viver em ambiente onde as celebrações religiosas eram particularmente importantes no contexto social, não esquecia o marquês das realizações profanas a que se habituara em Salvador (MATTOS, 1997, p.28).

Em meio a essas transformações sociais e urbanas surgem os primeiros teatros da cidade, então denominados casas de ópera. A primeira casa de ópera teria sido a do padre Ventura, ou Boaventura, com localização pouco clara e nenhuma iconografia ou localização em mapas (FAGERLANDE, 1998, 2012; CAVALCANTI, 2004, BRESCIA, 2010), mas citada somente em documentos e antigos relatos. A primeira casa de ópera é a chamada Ópera Nova, criada pelo mesmo Padre Ventura junto ao Paço (CAVALCANTI, 2004), e que tem a datação de 1758 como o primeiro registro de sua existência (CUNHA, 1971), e que após 1775 passa a se denominar Casa de Ópera de Manoel Luiz (FAGERLANDE, 1998). Construída ao lado do palácio do governo, passa a ser frequentada não somente pelo vice-rei, mas por toda a elite local e pelos visitantes estrangeiros que vinham à cidade.

Sua localização junto ao centro de poder da colônia (SISSON, 2008), além dos eventos ali realizados e sua estreita relação com o poder dos vice-reis e depois real mostram um novo momento dessa sociedade em que os usos civis vão se desenvolvendo, ainda que muito ligada à religião e aos espaços religiosos. Esse novo espaço de lazer e cultura trouxe para a cidade novas possibilidade de encontros, como um espaço característico desse momento de invenção da liberdade, como fala Starobinski (1994), ainda que menos política, mas de uma liberdade social, como novos usos e costumes se estabelecendo, ainda que diferente dos grandes centros europeus, mas como um novo lugar, tanto em seu interior como em sua relação urbana, nessa nova cidade do século XVIII caminhando para o XIX.

$\mathrm{O}$ artigo foi realizado a partir de pesquisa em que foi consultada ampla bibliografia sobre a cidade e sobre os espaços teatrais, a história do teatro no Brasil, e mapas sobre a

${ }^{5}$ D. Luís de Almeida Portugal, $5^{\circ}$ Conde de Avintes e $2^{\circ}$ Marquês do Lavradio, governador da Bahia em 1768/1769, vice-rei no Rio de Janeiro de 1769 a 1779 (LAVRADIO, 1978).

(c) Urbana: Rev. Eletrônica Cent. Interdiscip. Estud. Cid.

Campinas, SP v.10, n.1 [18]

p. $104-130$

jan./mai. 2018 
cidade naquele momento, buscando relacionar a construção do teatro com mapas que trouxessem essas informações (FAGERLANDE, 1998). O trabalho de Cavalcanti (2004) trouxe mais informações a partir de uma pesquisa documental, confirmando a pesquisa de Fagerlande, e incluindo novas informações. O trabalho de reconstituição hipotética feito por Fagerlande (1998) é reforçado pelo que Cavalcanti (2004) traz em seu livro, e foi realizado a partir dos mapas da cidade e de fotografias do edifício, que somente foi demolido em 1910 (FAGERLANDE, 1998), possibilitando um trabalho de levantamento de plantas e fachadas, levando ainda em conta o modelo interno e externo do teatro de Ouro Preto, contemporâneo e ainda em funcionamento (DIAS, 2012).

O estudo da sociedade portuguesa e da presença da edificação teatral naquele contexto aparece em obras de autores como Alves (1993) e França (1965). A pesquisa da história da cidade, possíveis citações ao teatro e mapas que revelassem algo sobre o teatro traz autores como Barrow (1806), Bougainville (1771), Cruls (1965), Cunha (1971), Ferrez (1985), Lima (2000), Luccock (1942), Luis Edmundo (1932), Santos (1943), Sisson (2008), Stauton (1798) e Vieira Fazenda (1921).

O papel do vice-rei Marquês do Lavradio é mostrado na obra de Lavradio (1942) e nas cartas do próprio Marquês do Lavradio (LAVRADIO, 1978), em que aparecem diversas citações ao uso da Casa de Ópera e seu estímulo às atividades ali realizadas, mostrando a participação oficial em relação às atividades do novo espaço teatral.

O estudo do teatro no Brasil e de seus edifícios tem autores como Fleuiss (1922), Hessel (1974), Marinho (1904), Mendonça (1926), Morais (1897), Paixão (1936), Ruy (1959), Saint Hilaire (1938), Silva (1938), Sousa (1960) e Versiani (1996) que mostram como se deu o inicio do teatro no Brasil e suas casas de espetáculo no século XVIII em diversas cidades, como Salvador, Rio de Janeiro e Ouro Preto.

Autores como Mattos (1997), Ayres de Andrade (1967), Fagerlande (1998; 2012), Nery e Castro (1991) trazem um olhar sobre a atuação de artistas daquele período, podendo estabelecer comparações entre os espaços religiosos e os laicos que surgem, e como esses artistas passaram a atuar em ambos.

\section{Os edifícios teatrais e o século das luzes}

$\mathrm{O}$ atual modelo teatral se estabeleceu a partir do Renascimento, em que se introduz o canto nas encenações, algo que possivelmente existiria na antiguidade também. Surge nesse momento a ópera, coexistindo com o teatro mais popular, inspirado nas encenações de rua. A

(c) Urbana: Rev. Eletrônica Cent. Interdiscip. Estud. Cid.

Campinas, SP V.10, n.1 [18]

p.104-130

jan./mai. 2018 
partir do século XVI surgem os edifícios teatrais, com exemplos como o Globe Theatre em 1596, utilizado por companhias que encenavam autores como Shakepeare. Na Espanha e em Portugal os primeiros teatros seguiram o modelo inglês, popularizando os espetáculos teatrais (COUTY, REY, 1995).

A Europa teve no século XVII um grande crescimento da construção de teatros, que passaram a ser espaços ligados ao poder, sendo muitos deles construídos pelos monarcas e suas cortes (STAROBINSKI, 1994). Na França os monarcas Luís XII e Luís XIV têm seus teatros construídos junto aos palácios reais, e em Versalhes, inaugurado em 1770, Luís XVI tem seu teatro dentro do próprio palácio (MORAND, 1970).

Nas características culturais desses dois séculos predominava o gosto pela encenação teatral na própria sociedade, com sua etiqueta, suas vestimentas, seu modo de agir e de viver. As festas encarnavam esse espírito na decoração, que incluía arcos triunfais, pavilhões temporários ou, mesmo, carros alegóricos para comemorar a ocasião, fosse um casamento nobre ou uma assunção ao trono. Se existiu liberdade criativa no momento barroco do século XVII, ela se ampliou significativamente com o advento do rococó, no século XVIII, permitindo ao artista não se prender a modelos preestabelecidos. Na verdade, esse foi o século em que as questões religiosas deixaram de ser o centro das atenções, e o mundo laico conquistou relevância. Os teatros foram exemplo bastante significativo da cultura desse momento, uma cultura de festa, segundo a análise de Starobinski (1994), que compara esses edifícios a templos. Prazer, liberdade e imitação da natureza, questões complexas num momento em que a organização política era a monarquia absoluta. Apesar disso, o homem começava a pensar e a vivenciar a liberdade, com o aflorar do Iluminismo, e mesmo os déspotas se diziam "esclarecidos".

Em Portugal a separação entre igreja e estado laico sempre foi mais difícil do que nos países centrais da Europa. Dessa maneira o teatro surge com aspectos um pouco diferentes das demais cortes do continente. Mesmo com a permanência do poder da igreja, o teatro teve importantes exemplares em terras portuguesas a partir de 1728 , com óperas encenadas no Paço da Ribeira, e novos teatros, como o da Rua dos Condes, de 1738, além de pequenos teatros populares, como o do Bairro Alto, de 1733, todos com apresentação de música italiana, em moda naquele período (NERY; CASTRO, 1991). A inauguração da Ópera do Tejo, em 1755, é ao mesmo tempo o apogeu e a queda da ópera em Portugal, pois no mesmo ano o grande terremoto a destrói, após poucos meses de vida.

(c) Urbana: Rev. Eletrônica Cent. Interdiscip. Estud. Cid. Campinas, SP $\quad$ v.10, n.1 [18] p.104-130 jan./mai. 2018 


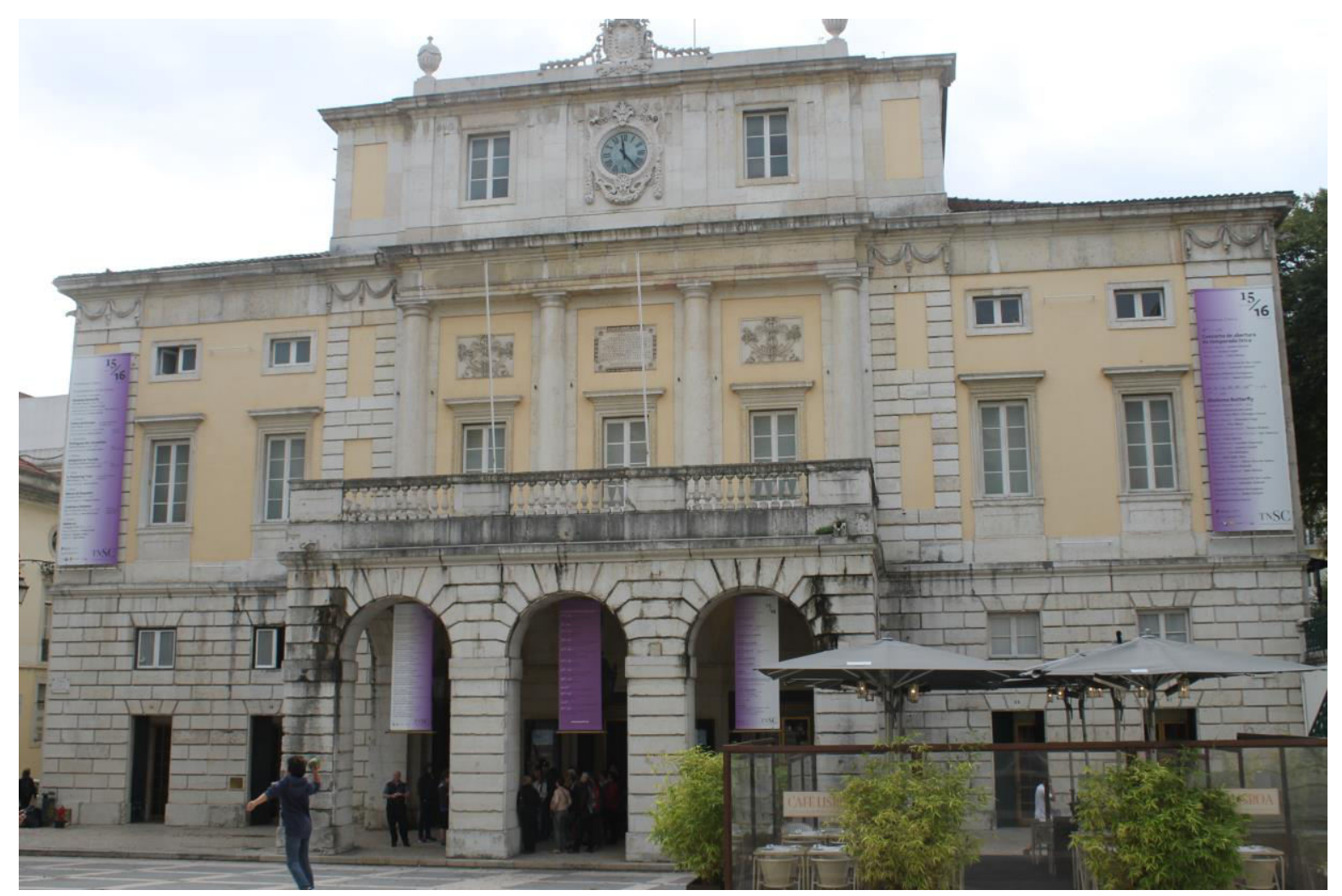

Figura 1 - Teatro São Carlos, Lisboa.

Fonte: Foto do autor, 2015.

A reconstrução de Lisboa por Pombal, levada a cabo em seguida, transforma não somente a capital, mas todo o reino. Dessa maneira é construída a nova Ópera Régia de Lisboa, em 1763, e nos jardins de Queluz passa a ser encenada a festa galante e o teatro, à moda de Versalhes (ALVES, 1993), e mais tarde é construído o novo grande modelo de teatro português, o Teatro São Carlos de Lisboa, de 1792, dentro do modelo Pombalino, inspirado no Teatro Scala de Milão.

A ideia da festa que se inicia no teatro e é transposta para a cidade muda as relações urbana existentes, pois existe o espetáculo da chegada ao teatro, da iluminação das ruas e dos cortejos de carruagens de quem vai assistir aos espetáculos. Ao mesmo tempo em que irão assistir criam um novo espetáculo de luxo nessa cidade que se moderniza tanto em termos de forma urbana com em termos desses novos usos cada vez menos ligados aos antigos hábitos religiosos. Antes a festa era somente religiosa, com as procissões e encenações religiosas e agora ela passa a ser também civil, como fala Starobinski (1994). 
DOI: $10.20396 /$ urbana.v10i1.8650899

\section{O teatro no Brasil}

No Brasil, no fim do século XVI, iniciaram-se encenações de espetáculos teatrais como parte das funções educacionais dos jesuítas. Eram autos e mistérios, com muita música, canto e dança, na realidade, ainda resquícios da tradição medieval trazida pelos colonizadores. 0 local de representação era o adro das capelas ou os impérios, palcos improvisados construídos junto aos templos para esse fim (PAIXÃO, 1936).

O uso de edifícios públicos para usos de encenações surge em Salvador, Bahia, que em 1729 de sala de espetáculos na Câmara de Vereadores da cidade, demolida em 1734 (HESSEL, 1974). Mais tarde em 1760 documentos mostram novo espaço construído para tal fim, o Teatro da Praia.

(...) edificara o Teatro da Praia, e nele tinha feito vinte e oito camarotes para assistirem óperas, e composições de plateia para divisão de povo e nobreza, e palanque para acomodação de mulheres comuns (RUY, 1959, p.26).

Vários lugares pelo interior do Brasil tiveram, no século XVIII, condições de ter seu pequeno teatro, sobretudo Minas Gerais, que, com o advento do ciclo do ouro e de diamantes, se tornou o local de maior concentração desses edifícios (DIAS, 2012). O Teatro de Ouro Preto, antiga Vila Rica, seria um dos mais antigos de Minas, tendo sido descrito por Saint-Hilaire em 1770:

Após subir-se uma rua excessivamente íngreme, chega-se a uma casa de aparência mesquinha; é lá que se fazem as apresentações. A sala é bastante bonita, porém pequena, e muito estreita. Tem quatro ordens de camarotes, cuja frente é fechada por balaustradas rendadas que não produzem mau efeito. Só os homens ficam na plateia, e ahi se sentam em bancos. Até agora não se tentou illuminar a sala de outra maneira que não a de se colocar velas entre os camarotes. A cortina representa as quatro partes do mundo pintadas de modo mais grosseiro; entre, porém, as decorações, que são variadas, ha algumas supportáveis. Os atores têm o cuidado de cobrir o rosto com uma camada de branco e vermelho, mas as mãos trahem a cor que a natureza thes deu, e provam que a maioria deles é de mulatos. Não tem a menor ideia de indumentária; e, por exemplo, em peças tiradas de história grega, vi personagens vestidos à turca e heroínas à francesa. Quando estes atores gesticulam, o que raramente sucede, poder-se-ia pensar que são movidos por molas, e o ponto, que lê

(c) Urbana: Rev. Eletrônica Cent. Interdiscip. Estud. Cid. 
as peças enquanto elles a declamam, fala tão alto que frequentemente sua voz mascara completamente a dos intérpretes. (SAINT HILAIRE, 1938, p.138).

Saint-Hilaire chama atenção para o pouco cuidado relativo à cenografia e às vestimentas. John Luccock (1942) registra ter estado nesse teatro quando de sua viagem a Minas Gerais, em 1817. Descreve-o como extremamente quente, situado em terreno irregular, com entrada pelos fundos, saguão e frisas no nível de entrada, camarotes dando para corredores, além de uma escada sombria, estreita e comprida, conduzindo a uma sala acanhada, sofrivelmente pintada, com plateia onde as mulheres não podiam ficar da mesma forma que os estrangeiros eram impedidos de frequentar as frisas.

Contemporâneo ao do Rio de Janeiro apresenta em essência o mesmo modelo: um edifício bastante simples externamente, no caso mineiro uma casa em ladeira, estreita e colada nas divisas, com um só andar na frente voltada para a rua, e os demais na declividade do terreno. O interior segue planta em forma de ferradura, com camarotes em duas fileiras dando na boca de cena, e, no fundo, o camarote principal, mais enfeitado do que os demais. As balaustradas são vazadas, como devem ter sido as do Rio, apesar de essas serem de ferro, e as do Rio de Janeiro, de madeira. O estado atual do Teatro de Ouro Preto, com pequenas divisórias entre os camarotes (DIAS, 2012), difere do anterior, de acordo com as citadas descrições de Saint-Hilaire (1938) e Luccock (1942). Assim como no Teatro de Manoel Luiz, haveria, possivelmente, cortinas ou divisórias de madeira entre os camarotes, bem como demarcando o espaço de circulação entre eles e a parede externa do edifício. Nos teatros europeus desse período, os camarotes já eram completamente isolados um a um, todos com antecâmara, limitada por cortinas, como o modelo hoje existente no Teatro Municipal do Rio de Janeiro. O palco ocupa todo o fundo do teatro, e, sob ele, dado o desnível do terreno, encontram-se os camarins. A atual escada de acesso também difere das descrições, pois não é comprida e sim do tipo "caracol".

O Teatro de Sabará (1819) é outro exemplo mineiro que se mantém até hoje, um pouco mais recente, mas, ainda assim, contemporâneo dos demais citados. São locais em que a nova situação econômica, junto com o distanciamento da Metrópole, criou condições de surgimento de cidades cujas necessidades eram atendidas não só por intervenção do Estado, mas por meio da iniciativa privada, por comerciantes que estabeleceram seus pequenos negócios, entre eles os teatros de província (FAGERLANDE, 1998; DIAS, 2012).

(c) Urbana: Rev. Eletrônica Cent. Interdiscip. Estud. Cid. Campinas, SP V.10, n.1 [18] p.104-130 jan./mai. 2018 


\section{Primeiros teatros no Rio de Janeiro: a Ópera Velha e a Nova, a Casa de Ópera de Manoel Luiz.}

Os registros dos primeiros teatros no Rio de Janeiro são escassos. Vieira Fazenda (apud FLEUISS, 1922) cita a existência de uma Ópera dos Vivos em 1705, mas não existe comprovação. Sousa (1960) se refere a processo de 1748 que fala da Rua da Ópera dos Vivos, o que sugere a existência do edifício naquele logradouro.

Citando diversos autores que falam da criação da Casa de Ópera do Padre Ventura, ou Boaventura, Cavalcanti (2004) traz documentação importante que comprova a existência desse teatro a partir de 1749, e escrituras de 1754 e 1775 a respeito do mesmo imóvel, o que é também confirmado por Brescia (2010), o que corrobora Vieira Fazenda (1921) que fala da existência de um pequeno teatro na cidade em 1748. Cavalcanti (2004) desenvolve uma representação hipotética do edifício, com plantas e um corte. Como ele mesmo reforça, esse estudo não tem base iconográfica, e é baseado em descrições de seu interior, e sua localização seria na Rua da Alfândega.

Com relação ao edifício estudado no presente artigo, a Casa de Ópera de Manoel Luiz, Cavalcanti (2004) diz que também teria sido construída pelo Padre Boaventura, e cita que em 1775 seu irmão e herdeiro se uniu a Manoel Luiz para gerir o novo teatro, o que é confirmado por Brescia (2010). A data de sua abertura seria 1758 ou 1760, de acordo com mapa da cidade no período (CUNHA, 1971).

Com certeza Padre Ventura, ou Boaventura foi importante personagem no cenário teatral do século XVIII no Rio de Janeiro. O fato do segundo teatro se localizar junto ao Paço tem com certeza grande importância, com contrário do primeiro teatro, distante dessa centralidade da cidade.

No Rio de Janeiro do fim do século XVIII, o grande centro de poder era o Largo do Carmo, ${ }^{6}$ com o Paço dos Vice-Reis, as Igrejas do Convento do Carmo e da Ordem Terceira, além de outros relevantes sobrados, como a Casa de Câmara e Cadeia, e do porto, marcado pelo chafariz do Mestre Valentim ${ }^{7}$, ligação única e vital com a metrópole e com o restante da colônia. A implantação urbana desse centro de poder do Rio de Janeiro é bastante semelhante à encontrada na grande Praça do Comércio de Lisboa, que "é a suprema expressão simbólica do urbanismo tradicional da Europa do domínio marítimo de uma grande nação" (SMITH, apud

\footnotetext{
${ }^{6}$ Esse local foi depois denominado Praça do Carmo, Terreiro da Polé, Largo do Paço, Praça Pedro II e, atualmente, Praça XV (FAGERLANDE, 1998).

${ }^{7}$ Colchete (2008) fala que o Paço real foi inaugurado em 1743, a Igreja do Carmo em 1761 e o chafariz do Mestre Valentim em 1789.
} 
SISSON, 2008, p. 43), segundo Robert Smith, citado por Rachel Sisson ao relatar a influência desse modelo como ponto inicial do desenvolvimento urbano, que se repete no Rio de Janeiro.

Se o edifício já existia quando o Marquês do Lavradio chegou à cidade, vindo da Bahia, seu uso se intensificou com o interesse do vice-rei pelo uso do teatro, e sua localização junto ao palácio facilitava o acesso, possibilitando que visitantes estrangeiros que chegavam à cidade fossem trazidos a eventos ali realizados (PAIXÃO, 1936). Nesse espaço central do poder no Rio de Janeiro a Casa de Ópera de Manoel Luiz, nome que o lugar tomou após possivelmente antes ter sido denominado Ópera Nova (CAVALCANTI, 2004; BRESCIA, 2010), foi possivelmente o primeiro teatro da cidade a contar com incentivo oficial, apesar de ter sido construído e mantido por particulares, inicialmente o Padre Ventura e depois Manoel Luiz Ferreira (PAIXÃO, 1936).

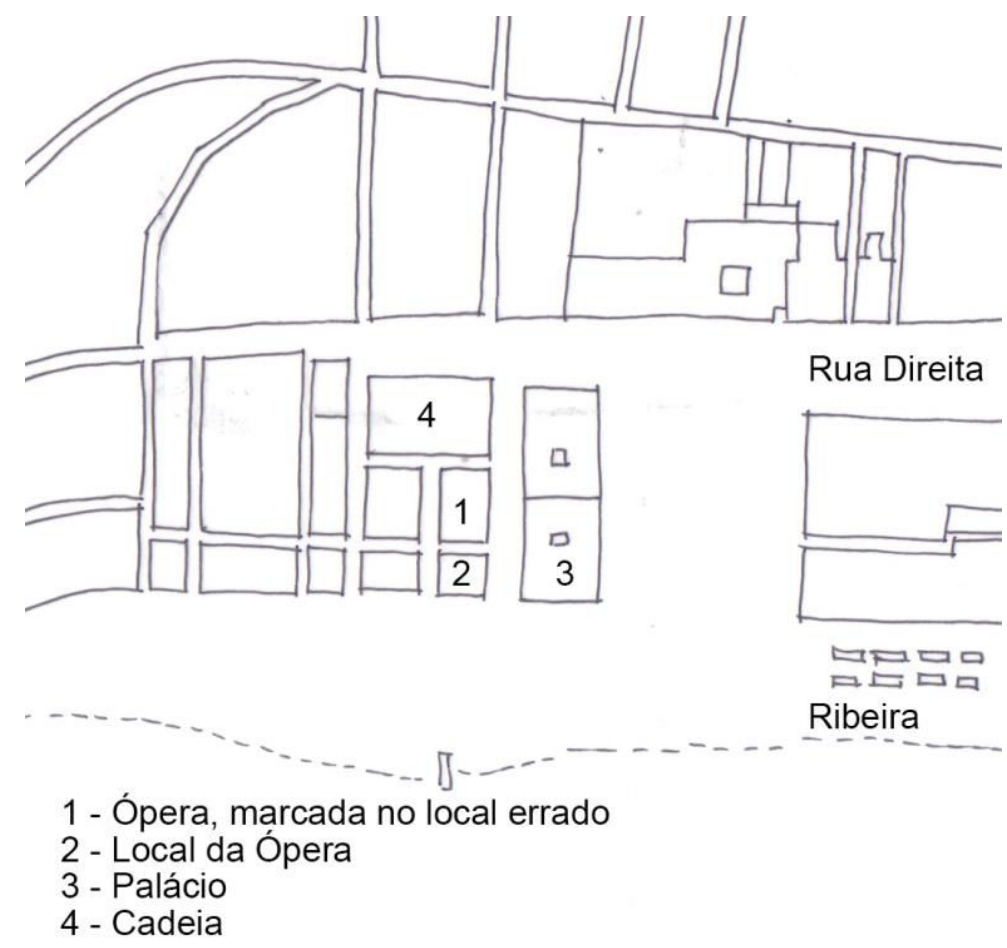

Figura 2: Planta de localização da Casa de Ópera em 1758/60 Fonte desenho do autor sobre mapa de 1758/60 (CUNHA, 1971).

O teatro foi construído na Praia de D. Manoel, junto ao Palácio dos Vice-Reis, atrás da Cadeia Velha e da Câmara. Tinha sua principal fachada, a de menores dimensões e pela qual se fazia a entrada, na Rua da Cadeia (atual Rua da Assembleia).

(c) Urbana: Rev. Eletrônica Cent. Interdiscip. Estud. Cid. 
Casa de Ópera de

Manoel Luiz /

Paço

Igreja do Igreja da Ordem

TeatroRégio
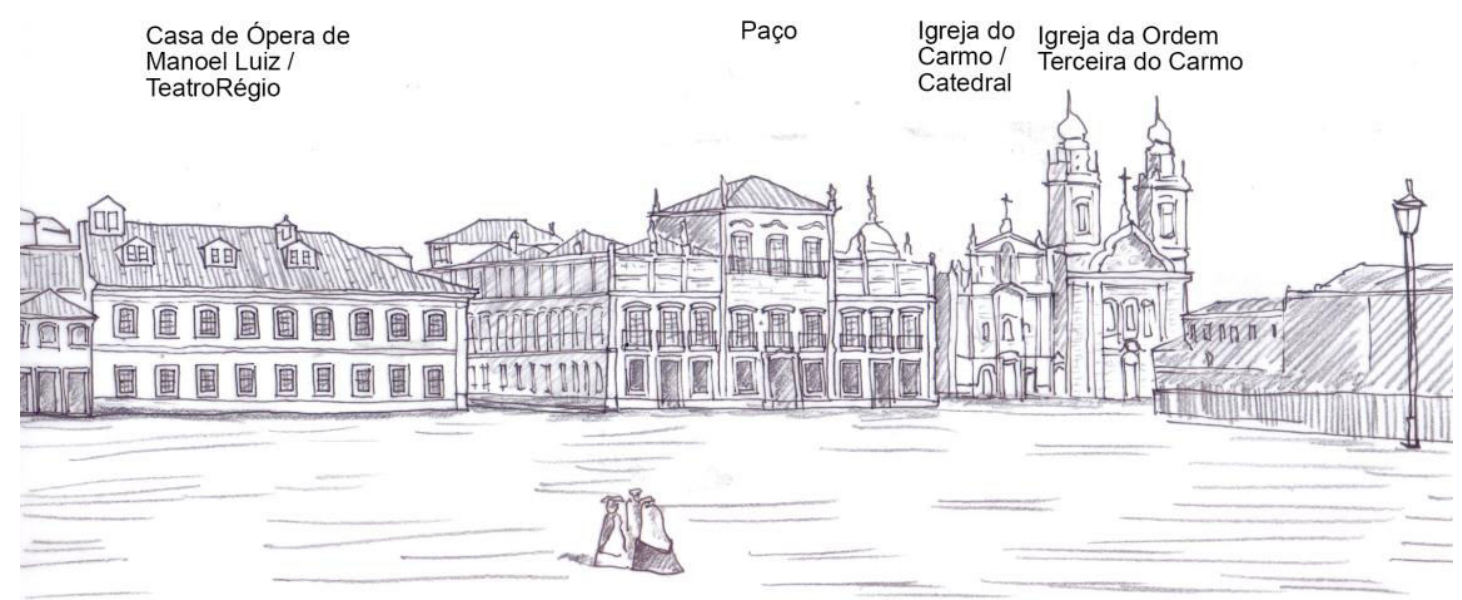

Figura 3: Casa de Ópera e o Paço em 1858

Fonte: desenho do autor, 2017.

Representação hipotética do edifício em 1776.

Travessa do Paço

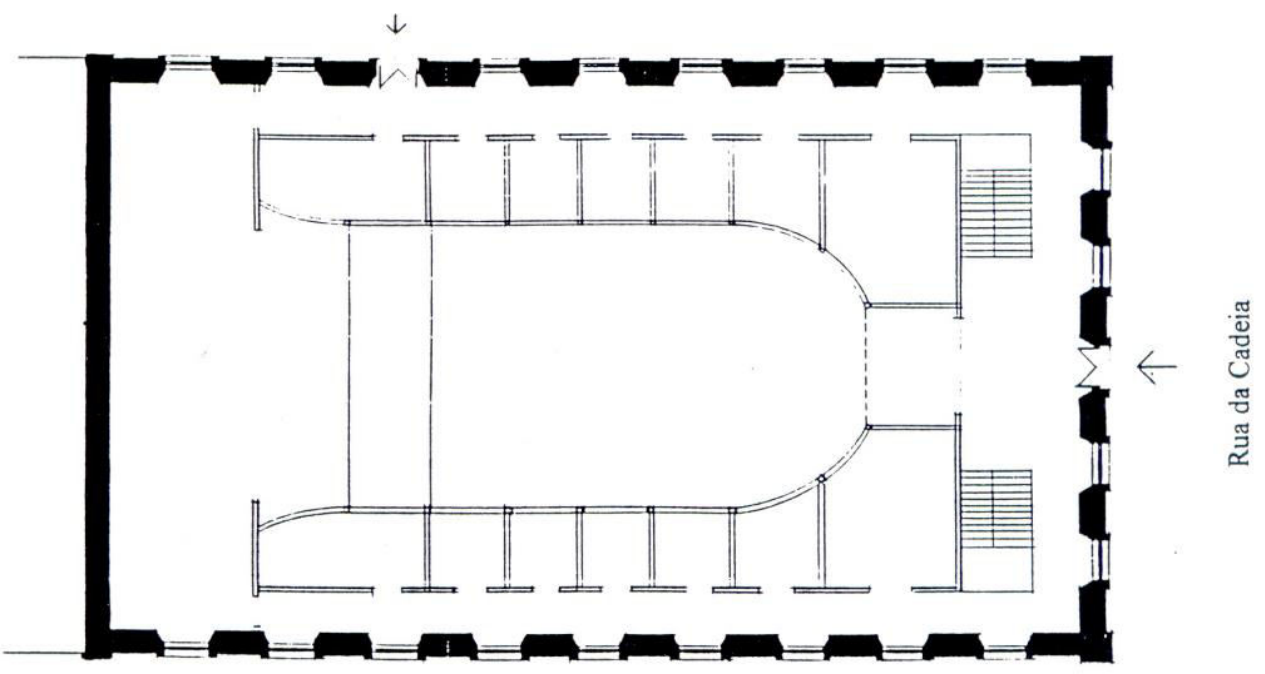

Largo do Carmo

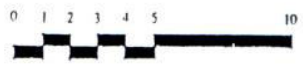

Figura 4: Casa de Ópera de Manoel Luiz - Planta baixa / pavimento térreo

Fonte: desenho do autor, 1998

(c) Urbana: Rev. Eletrônica Cent. Interdiscip. Estud. Cid. Campinas, SP V.10, n.1 [18] p.104-130 jan./mai. 2018 


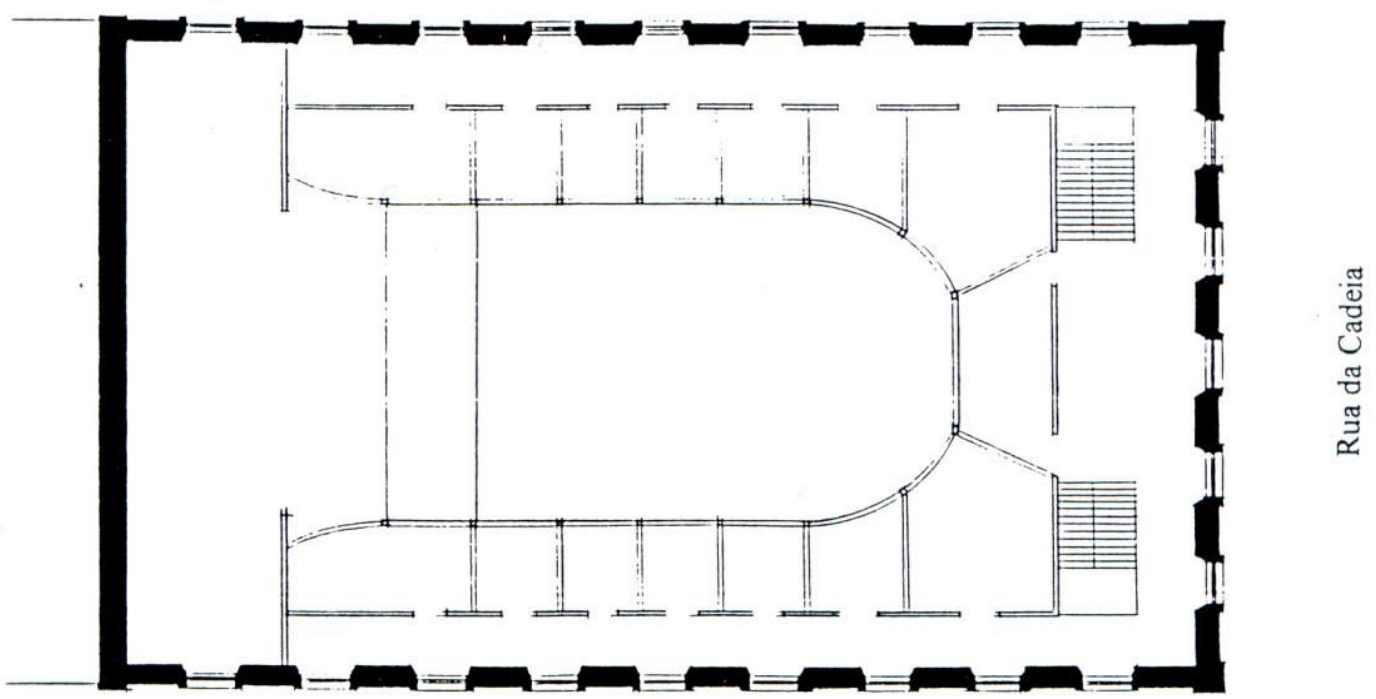

Largo do Carmo

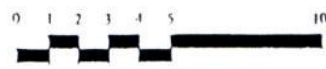

Figura 5: Casa de Ópera de Manoel Luiz - Planta baixa / pavimento superior

Fonte: desenho do autor, 1998

Um de suas fachadas laterais estava voltada para o Largo do Carmo, onde estava localizado o porto da cidade e o espaço de poder mais significativo da época colonial (SISSON, 2008), a fachada principal para a Rua da Assembleia, via lateral do Paço, e a outra fachada lateral para a Travessa do Paço. Sua localização nobre, junto ao edifício onde se localizava o maior representante do poder no Rio de Janeiro e no Brasil, poderia ser comparada ao modelo de teatro de Versalhes, que faz parte do corpo do próprio palácio. Por outro lado, a construção muito simples mantinha certas características arquitetônicas da época, como o próprio Paço, projetado por Alpoim, e seguindo o que ocorria com diversas igrejas do Centro do Rio de Janeiro, excetuando-se as conventuais, com a a porta de acesso principal pouco destacada por largo ou, mesmo, por uma rua mais larga. Esse modelo de implantação urbana somente seria rompido em 1813, com a inauguração do Real Teatro São João, quando se verifica a valorização da fachada principal, desta vez seguindo o modelo do Teatro São Carlos de Lisboa (LIMA, 2000).

(c) Urbana: Rev. Eletrônica Cent. Interdiscip. Estud. Cid.

Campinas, SP 


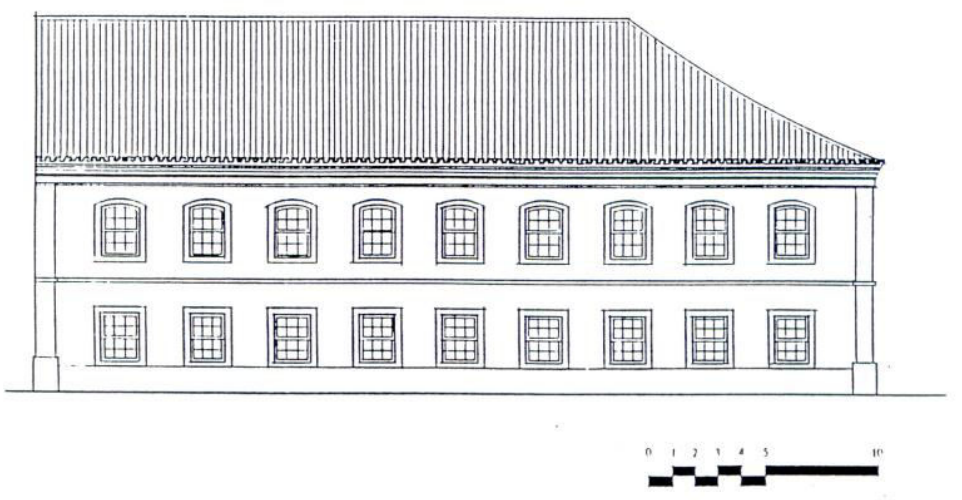

Figura 6: Casa de Ópera de Manoel Luiz - fachada lateral para o Largo do Paço Fonte: desenho do autor, 1998

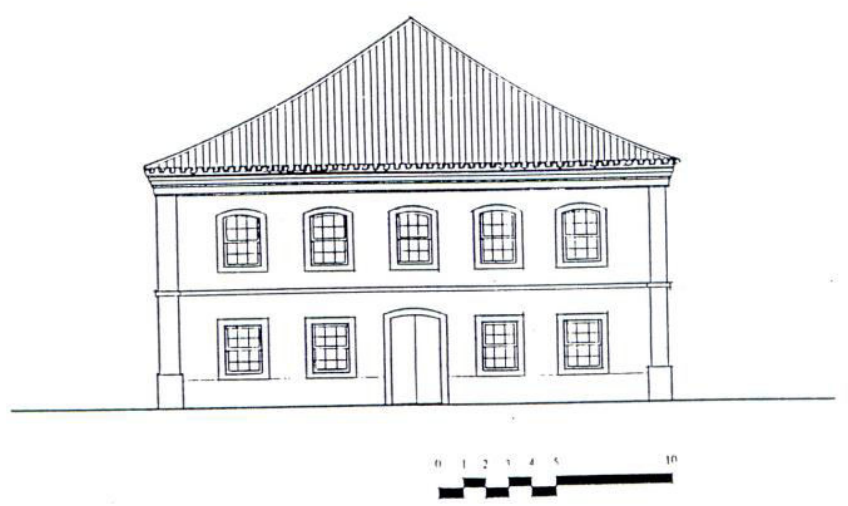

Figura 7: Casa de Ópera de Manoel Luiz - fachada frontal para a Rua da Assembleia Fonte: desenho do autor, 1998

Após o início da administração do teatro por Manoel Luiz, sua reinauguração, provavelmente em 1776, registra a presença do poeta mineiro Alvarenga Peixoto (PAIXÃO, 1936), embora outros autores, como Mattos (1997) afirmem ter sido Silva Alvarenga o poeta que participou dessa inauguração, tendo mesmo recitado um poema em homenagem ao marido da Rainha D. Maria I. De qualquer modo, ambos, assim como Claudio Manoel da Costa, estiveram ligados a esse teatro, onde foram encenadas peças de sua autoria, como Enéas no Lácio. Esses fatos mostram que a intelectualidade da época, incluindo importantes poetas 
mineiros posteriormente ligados à Inconfidência e às novas ideias liberalizantes, teria participado da vida cultural carioca daquele momento, em intercâmbio que o teatro iria dinamizar, mostrando a importância do espaço teatral para a divulgação dos novos ideais de liberdade.

A inauguração atraiu músicos, atores e dançarinos de diversos pontos do país, interessados em participar de seus elencos. Sem dúvida foi casa de categoria melhor do que a do primeiro Teatro do Padre Ventura (MATTOS, 1997), em local mais adequado para a apresentação de peças dramáticas, entremeadas ou não de música. Relatos do próprio Marquês do Lavradio, descrevendo as pessoas que assistiam aos espetáculos, entre elas as senhoras de sociedade, mostram o inicio da presença feminina no teatro, em outra importante mudança social que o teatro veio a trazer para a sociedade da época:

A ópera era divertimento predileto das fluminenses, onde creio que os seus confessores as mandam ir, assim a elas como a seus maridos, em satisfação das suas culpas e pecados, porque cada uma delas se acha no seu camarote com o seu marido, ambos em grandíssima melancolia, ele sem se resolver a ir fora, nem para as operações a que a natureza está sujeita, nem a olhar e dar confiança que ninguém tenha a honra de ir fazer-Ihe os seus cumprimentos (LAVRADIO, 1942, p. 22).

Outro exemplo da relação direta entre os novos usos do teatro e a vida da cidade são descrições de que, em 1792, bandos de timbaleiros percorriam o Rio de Janeiro alardeando o espetáculo, com roupas de arlequim ou camisas negras com chapéus afunilados, à maneira de figurinos tirados da commedia dell'arte, de uma forma que mais pareciam artistas de rua do que personagens de um teatro bem-estabelecido, mostrando a influência do teatro de rua, vindo da Itália através de Portugal (SOUSA, 1960). Essas descrições coincidem com festejos que ocorriam em Portugal, onde, existem notícias de que após a publicação de carta régia comunicando e divulgando a motivação da festa, um grupo de artistas percorria a cidade aa fim de informar o acontecimento e convidar para as comemorações (ALVES, 1993).

O público que comparecia aos espetáculos é mencionado por Morais, que salienta a presença da nobreza no teatro e o fato de o povo ficar do lado de fora, aproveitando os restos do espetáculo.

Preparada com riqueza a Casa de Ópera, concorrida em suas representações pela fidalguia opulenta e formosura aristocrática, os espetáculos deslumbravam com o esplendor o povo da colônia, que se apinhava em derredor do teatro para extasiar-se

(c) Urbana: Rev. Eletrônica Cent. Interdiscip. Estud. Cid.

Campinas, SP v.10, n.1 [18]

p.104-130

jan./mai. 2018 
dos sons da música e ver entrar o Vice-Rei e seu estado-maior, as senhoras e os nobres senhores, que desciam de suas traquitanas pesadas e balouçantes (MORAIS, 1897, p. 193).

Como vemos o espetáculo para o "povo" era, na verdade, a representação da nobreza e da fidalguia, exibindo suas roupas, joias e carruagens, da qual a população só participava pelo lado de fora, da mesma maneira que as camadas populares eram inibidas de frequentar o Passeio, dito, Público da cidade, cujo muro reiterava a divisão de classes. Mesmo assim a nova visão do luxo e do espetáculo, não somente o que ocorria dentro, mas o que era mostrado fora nas ruas da cidade trazia a novidade da exposição do que antes era visto somente nos palácios e casas nobres. O fato de a festa ocorrer em um espaço civil, não somente na igreja, era também algo novo.

Através de relatos de estrangeiros, como Bougainville (1771), podemos conhecer melhor não somente os usos do teatro como seu interior. Sua descrição da Casa de Ópera nos mostra a relação com o Vice-Rei, mostrando a importância do espaço e as obras que ali eram representadas, e de como a recepção ocorria tanto no espaço do teatro como ao ar livre, comprovando as mudanças na cidade, lembrando a festa europeia que se reproduzia na colônia.

No entanto, a atenção do vice-rei conosco continuou por vários dias; ele até nos anunciou algumas pequenas ceias, que ele propôs nos dar nas margens da água sob os berços de jasmim e laranjeiras, e ele nos fez preparar um camarote na Ópera. Em um salão bastante bonito, podíamos ver as obras-primas de Metastasio representadas por uma trupe de mulatos e ouvir as peças divinas dos grandes mestres da Itália, executadas por uma orquestra dirigida por um padre chefe em seu hábito eclesiástico (BOUGAINVILLE, 1771, p.58).

Por certo o regente seria o Padre Ventura, e o espetáculo teria ocorrido na Ópera Nova, anterior à Casa de Ópera de Manoel Luiz, de 1776. Stauton (1798) registra mesmo que as festas se limitavam então ao Passeio Público, onde aconteciam banquetes com música e fogos de artifício, a versão local da festa rococó dos jardins e parques da Europa, esta sabidamente bastante documentada por pintores como Fragonard e Watteau.

Consta que, em 1792, numa de suas estadas no Rio de Janeiro, Tiradentes esteve no teatro, onde, da plateia, teria feito propaganda política de seus projetos hidráulicos para a cidade, ainda que sem muito sucesso (VERSIANI, 1996). Dessa maneira mais uma vez o teatro 
se ligava aos acontecimentos políticos e culturais, em mais uma demonstração de sua importância para os novos tempos e novos pensamentos da época.

Com o retorno do Marquês do Lavradio para Portugal, o teatro perdeu parte de seu brilho, sendo fechado por volta de 1792, por ordem da rainha D. Maria, voltando, entretanto, a abrir posteriormente suas portas, fato comprovado por relatos de viajantes ingleses da época, como Stauton (1798) e Barrow (1806).

O uso do teatro para atividades cívicas e comemorações oficiais evidencia também sua crescente importância nessa sociedade. Silva (1938) relata haver no arquivo da prefeitura um recibo passado ao coronel Manoel Luiz Ferreira, em 27 de agosto de 1806, pelo aluguel da Ópera, ajustado pelo Senado para a posse do novo governo do vice-rei Conde de Arcos. E Fleuiss informa sobre a decoração elaborada para o aniversário do rei D. José, com adereços de candelabros de prata, panejamentos carmezins franjados de ouro e riqueza oriental, ressaltando mais uma vez o luxo empregado em espaço que, mesmo sendo particular, passara a ser utilizado de forma coletiva pela sociedade da época.

No aniversário de D. José I, costumava haver espetáculo de gala, o Teatro de Manoel Luiz tornava-se uma verdadeira maravilha de ornamentação e luzes. O povo apinhavase na Praça do Carmo para ouvir a música e os aplausos da plateia e ver o Vice-Rei, as damas, os fidalgos, recamados de sedas, veludos, oiros e plumas e pedrarias, saltar das sacolejantes traquitanas da época à porta da Ópera (FLEUISS, 1922, p. 1536).

Durante essas festas, bem como nas comemorações de nascimentos ou casamentos de reis e príncipes, o Senado da Câmara obrigava-se a favorecer a população com a apresentação de "óperas francas", isto é, gratuitas, no Teatro de Manoel Luiz (FLEUISS, 1922). O próprio empresário gerenciava esses festejos e outros, que incluíam espetáculos na Praça do Curro, posteriormente Campo de Santana, até mesmo praças de touros.

A Casa de Ópera de Manoel Luiz passou por duas fases distintas. A primeira correspondeu ao período em que o Brasil era vice-reino, e o Rio de Janeiro, sua capital, quando as atividades não apresentavam ampla variedade, mesmo contando com as diversas festas comemorativas. A segunda teve início com a chegada da família real em 1808, quando o edifício passou a ser denominado Teatro Régio, e durou até a construção do Real Teatro de São João, quando fechou suas portas ao público, em 1813 passando à condição de mera dependência do Paço (FAGERLANDE, 1998). Nesta última fase foram ali encenadas as primeiras óperas do padre José Maurício Nunes Garcia, outras do grande compositor lusitano

(c) Urbana: Rev. Eletrônica Cent. Interdiscip. Estud. Cid. Campinas, SP V.10, n.1 [18] p.104-130 jan./mai. 2018 
Marcos Portugal e também os primeiros bailados apresentados no Brasil (MATTOS, 1997). Foi um período de grande atividade, em que o teatro passou a ter relação mais direta com o poder real, apesar da predileção de D. João VI pelas festas religiosas.

O edifício teve novas mudanças nesse período após a chegada da corte, ganhando um terceiro pavimento por cima dos camarotes. Essa ampliação visava comportar mais pessoas no teatro, uma vez que se verificava grande desenvolvimento populacional na cidade. O novo pavimento estaria reservado à camada mais popular, incluindo os funcionários da corte. As representações também sofreram alterações, com novas peças musicais e teatrais, com um elenco aumentado, e com uma orquestra aprimorada com os músicos vindos com a corte. A presença de estrangeiros e suas descrições nos mostram como eram as diversões da época e o espaço do teatro, como na fala John Luccock, que esteve no Brasil de 1808 a 1818

Entre os locais de divertimento público e recreação de uma cidade grande, o teatro, em geral, ocupa o lugar mais importante... O teatro se acha situado rente ao Paço e é uma casa miserável, apertada e sombria. Por dentro sua forma é oval, tendo numa das extremidades o palco e na outra o camarote real que ocupa toda a parede norte do edifício. Outros com o ar livre, e quente a mais não poder, estendem-se em redor dos lados, munidos pela frente de um gradeado de rótula, bizarramente pintado. A plateia é dividida em duas partes: a que fica de frente do camarote real possui tamboretes, com uma trave de encontro à qual podem descansar os ombros; a que fica por detrás desta e por baixo do camarote real é separada por um baluarte, e a parte do auditório que ali fica tem de ouvir de pé. O recinto é iluminado com candeeiros de estanho fixados aos pilares que sustentam os camarotes, e por um candelabro de madeira com braços de estanho. A cena e as decorações correspondem exatamente a este mobiliário. Por todos os cantos da casa, bem como em todas as avenidas que para ela conduzem, acham-se postadas sentinelas de baioneta calada (LUCCOCK, 1942, p. 60).

Mesmo sendo uma descrição que traça um perfil pouco favorável ao edifício, como muitas vezes ocorre com a visão dos estrangeiros que tendiam a estabelecer comparações com o que existia na Europa, é significativa descrição que revela a forma da planta do teatro, com seu interior oval, forma que o autor mencionou provavelmente querendo dizer em ferradura, arco ovalado terminando em parte reta, o palco. Apresenta também uma modificação relativa à localização do camarote real, que se desloca da frente para o fundo da sala, mantendo-se, entretanto, bastante amplo. E, finalmente, permite concluir que os

(c) Urbana: Rev. Eletrônica Cent. Interdiscip. Estud. Cid. Campinas, SP V.10, n.1 [18] p.104-130 jan./mai. 2018 
interiores eram decorados, com balaustradas pintadas e em rótulas, havendo, já nesse momento, assentos para os espectadores mais privilegiados.

O padre Perereca, Luís Gonçalves dos Santos, descreve um importante evento ocorrido no corte, o casamento do D. Pedro Carlos de Bourbon e Bragança, infante de Espanha e sobrinho do regente D. João, com a filha deste último, D. Maria Tereza, A descrição do casamento, em 1810, mostra que as núpcias que começaram na Igreja e continuaram no Teatro ao lado, terminando com uma festa em plena praça, reafirma a importância do teatro e do espaço público da cidade junto a ele:

Após cerimonia religiosa, pelas nove horas, passaram Suas Altezas para o Teatro, que estava ornado com magnificência, achando-se já ali toda a nobreza, por especial convite, grande número de senhoras ricamente adornadas e um numeroso concurso de pessoas distintas de diferentes hierarquias. Após os vivas à Família Real, os cômicos passaram a desempenhar um novo drama intitulado "O Triunfo da América", composto para se recitar nesta faustíssima noite (SANTOS, 1943, p 324).

Ao lado da descrição do espaço, que mostra algum luxo e como o espaço ainda era importante, uma vez que abrigava a celebração das núpcias de membros da família real, mostra que a presença feminina passava a ser permitida em espaços que não mais somente as igrejas, uma novidade na cidade daquele momento. Mostra ainda a importância do teatro na festa no Brasil do inicio do século XIX, da maneira como ela é descrita por Starobinski na Europa desde o século XVII.

A chegada da corte fez com que as atividades do teatro tivessem impulso até seu fechamento em 1813 (AYRES DE ANDRADE, 1967). Em 1803, o padre José Maurício Nunes Garcia, mulato, mestre capela do rei e grande compositor sacro, apresentou a abertura sinfônica Zemira, como introdução ao elogio dramático ${ }^{8}$ no aniversário do vice-rei D. Fernando José de Portugal, e outra abertura, intitulada A Tempestade, para outro elogio dramático. Em 1809, compôs música de cena para peças dramáticas de D. Gastão Fausto da Câmara e Coutinho, Ulissea, em homenagem a D. João VI. Eram tentativas do padre de popularizar sua produção, ultrapassando a esfera do sacro. Na semana santa de 1809, o bispo D. José Caetano escreve em seu "Livro de Apontamentos":

${ }^{8}$ Elogio dramático, segundo Sacramento Blake, in Dicionário Bibliográfico Brasileiro, 1883, V 5, p.89, era gênero literário muito em voga no Brasil Colônia, apresentado sob pretextos vários: casamentos, aniversários e outras festas. Geralmente eram elaborados em estilo gongórico e realizados em oportunidades para louvar autoridades, da família real ou da própria colônia. 
DOI: $10.20396 /$ urbana.v10i1.8650899

Pediu-se licença para se representar no Teatro Régio vários Oratórios, como a Epiphania ou Tempo de Religião, Samsão e Dalila. Pela Parte que nos pertence, não devemos autorizar semelhante espetáculo no santo tempo da Quaresma, e de penitência, porque esperamos que nos sagrados templos e nos exercícios e práticas da Igreja acharão os fieis de mais segura edificação (MATTOS, 1997, p. 234-236).

O que demonstra algum interesse público em transferir a celebração musical do templo religioso para o pagão, ainda que sem muito sucesso. Outra descrição de Ayres de Andrade (1967) aponta, em 1811, acontecimento teatral de vulto, que encaminhou "para o Teatro Régio a sua aristocrática clientela dos grandes dias" - a estreia de Marcos Portugal, com a ópera L'Oro Non Compra Amore.

Marcos Portugal era o maior compositor português da época e chegou ao Rio de Janeiro disputando o cargo de maior compositor da corte com o padre José Maurício, em clara interferência portuguesa nos indícios de nossa brasilidade. Com ele vieram artistas estrangeiros, como o bailarino e coreógrafo francês Louis Lacombe, que, no citado espetáculo, com0 cantores italianos e brasileiros, apresentou o bailado I Due Rivali, inaugurando a tradição de dança no Brasil. Não se tem notícia da situação anterior a esses espetáculos, mas documentos destacam a preocupação oficial com relação aos mesmos, no sentido de garantir aos espetáculos líricos ali realizados um feitio artístico mais europeu, condizente, segundo as autoridades, com um estabelecimento que se chamava Teatro Régio. Comunicação existente no Arquivo Nacional registra:

Para Manuel Luís Ferreira. Tendo acontecido por várias vezes não serem executadas na real presença do Príncipe Regente Nosso Senhor com a regularidade devida algumas peças de música que se têm recitado no teatro de v. mcê.: foi o mesmo Senhor servido, para evitar esta falta de execução, dar as providências que julgou convenientes a êste respeito, encarregando a Marcos Portugal, mestre de música de suas Altezas Reais, a inspeção e direção, de comum acordo com v. mcê., dos espetáculos que se destinarem para os dias em que Sua Alteza Real fôr ao teatro na forma do Aviso da cópia inclusa na data de hoje, que remeto a v. mcê. Para sua inteligência. Deus guarde v. mcê. Paço em 9 de outubro de 1811. Conde de Aguiar (AYRES DE ANDRADE, 1967, p.70).

(c) Urbana: Rev. Eletrônica Cent. Interdiscip. Estud. Cid. Campinas, SP $\quad$ v.10, n.1 [18] $\quad$ p.104-130 jan./mai. 2018 
Por certo após a chegada da corte e com o crescimento da cidade, e certa valorização da atividade teatral, houve necessidade de um teatro maior, o Real Teatro São João, que seguia o modelo do Teatro São Carlos de Lisboa, inaugurado em 1793, em uma implantação com maior destaque, e uma área de expansão da cidade, onde hoje se localiza a Praça Tiradentes. O Teatro Régio perdeu sua função, e seu edifício passou a ser ocupado por sucessivos órgãos públicos, tendo sido requisitado para residência de funcionários do Paço Real (moradia de criados) e tesouro do Paço (Tesouraria da Casa Imperial), Almoxarifado da Casa Imperial, Ucharia (despensa) do Paço, agência da Estrada de Ferro D. Pedro II, dependência da Inspetoria Geral das Terras e Colonização, depósito da Repartição Geral dos Telégrafos e Estação do Corpo de Bombeiros. Foi demolido em 1903, e, em seu lugar, juntamente com a antiga Cadeia e Assembleia, foi construída mais tarde a nova Assembleia Legislativa (FAGERLANDE, 1998).

\section{Considerações finais}

No resgate da história dos teatros do Rio de Janeiro no século XVIII, principalmente do Teatro de Manoel Luiz, buscou-se formar uma imagem de sua história, arquitetura e relação com os novos costumes de uma cidade que foi se modificando, de uma pequena cidade colonial que acabava de se tornar sede do vice-reino a uma cidade capital de um império colonial europeu, após a chegada da corte em 1808.

A partir de relatos, ainda que por vezes contraditórios, junto com o material iconográfico encontrado e a bibliografia existente, foi possível ter uma base para uma imagem bastante real do estabelecimento não apenas no sentido físico, de suas fachadas e plantas mostrando seu exterior e interior, mas também quanto a suas variadas atividades e de suas relações urbanas, durante seus cinquenta e cinco anos de funcionamento.

O levantamento iconográfico, as descrições e a documentação de citações das festas, óperas e solenidades que aconteceram no período de 1758 a 1813, durante a existência do teatro enquanto Casa de Ópera de Manoel Luiz e Teatro Régio comprovam, além de sua própria existência e de sua importância, a presença, num Rio de Janeiro anterior à chegada da corte e da Missão Francesa, de significativo movimento cultural e musical. A encenação de obras estrangeiras e brasileiras, como as peças do italiano Metastásio e do francês Molière, as dos mineiros Cláudio Manoel da Costa e Alvarenga Peixoto, e do carioca Antônio José, o Judeu, bem como as óperas do lusitano Marcos Portugal e do mulato carioca padre José Maurício, além dos primeiros bailados, evidenciam a relevância desse espaço de arte e cultura na cidade do Rio de Janeiro. 
É importante observarmos que esse teatro marcou um novo momento na vida da colônia, introduzindo um hábito laico numa sociedade ainda marcada por forte presença da Igreja. A desvinculação da festa religiosa foi de grande importância nesse momento, pois criou as bases para um novo século em que o país se abriu para o mundo e suas influências, tanto econômicas quanto culturais. As relações do edifício dentro da cidade, em que essa festa não se restringia ao seu interior reafirma a importância urbana desse edifício.

A questão do teatro como espaço de uma festa iconoclasta explica a necessidade desse tipo de edificação agora presente na vida da cidade. Na Europa, a questão é bem apresentada em teatros característicos do século XVIII, exemplos de uma civilização de luxo e prazer, substitutos dos templos enquanto lugares privilegiados da elegante frivolidade da época, onde se podia desenvolver a exaltação literária e musical. Filósofos como Diderot e Rousseau vão confrontar a função ideal do teatro com sua realidade presente: espaço potencial para a comunhão entre as pessoas reunidas em torno de um único objetivo, uma única atividade, na verdade, propicia o pavoneamento do público, tornando-se local de demonstração das diferenças. A separação começa na própria estrutura física, pois o edifício, em vez de reunir, marca fronteiras entre as classes presentes. A turbulência da plateia coletiva é bem separada dos camarotes que são individuais, reforçando a ideia de divisão da sociedade.

Enquanto Portugal vivia o século XVIII de maneira difícil, com conflitos entre as posições mais liberais em que o teatro e a ópera tinham espaço, refletido na construção da Ópera do Tejo e depois do uso do Palácio de Queluz para grandes festas, a religião ainda era elemento preponderante, com a Igreja e as missas tendo mais destaque que a festa barroca.

Lisboa, segundo seu novo projeto urbano e arquitetônico, não garantiu lugar para o teatro real, mas sim para o novo teatro burguês, incentivado por Pombal. Pequenos teatros seguiram esse padrão, que teve seu apogeu arquitetônico com a construção do Teatro São Carlos, em 1793. Em Queluz, nos jardins do palácio, o antigo modelo de teatro vinculado ao edifício real permaneceu.

No caso do Brasil, essas questões se conciliam. O Teatro de Manoel Luiz, ao mesmo tempo em que seguiu o antigo modelo da ópera ligada ao Palácio, como na Ópera do Tejo ou no Teatro de Queluz, foi construído e mantido por particulares, tanto Padre Ventura quanto Manoel Luiz, que, assim, cedeu ao modelo pombalino. Trata-se de um misto dos dois padrões, cumprindo dessa forma o importante papel de elo dessa corrente, que terá, finalmente, seu grande teatro em 1813, construído por burgueses, e distante do palácio, ainda com o aval do regente, denominado Real Teatro São João. 
Com relação a sua arquitetura e sua relação urbana, segue as linhas ditadas pela arquitetura de Alpoim no Palácio dos Governadores, mantendo implantação comum às igrejas do período, com sua entrada principal voltada para pequeno beco, e não para o importante largo vizinho. De qualquer maneira, sua localização urbana demonstra a nova importância, especialmente se comparada à do primeiro Teatro do Padre Ventura, por não ser mais uma pequena rua distante, mas no centro de poder.

Mesmo em um edifício pouco luxuoso exteriormente, o interior apresentava alguma ornamentação de destaque, com materiais nobres para aquele momento da colônia. A presença externa da população era um forte indicio da importância da atividade na cidade, com o povo do lado de fora ouvindo a música através das janelas e aproveitando da festa apenas a chegada dos nobres e ricos em seus coches. O teatro deixava então de ser uma festa popular, tornando-se celebração da nobreza e burguesia.

Toda essa novidade quer sejam de cunho artístico ou de costumes, não poderiam acontecer sem um espaço específico. A valorização atribuída ao teatro seja em sua localização dentro da cidade, seja em seu uso festivo e comemorativo, refletia essa sociedade que caminhava para o século XIX, em que a "civilidade" se fez gradualmente mais presente. Essa sociedade leiga fez uso desse novo espaço para festas, inicialmente, de modo mais "popular" e burlesco, tornado, entretanto, com a chegada da corte, mais erudito e sofisticado, na tentativa de criar uma atmosfera de corte europeia, mesmo nos trópicos e com uma família real decadente. O teatro em meio à cidade reforça a importância urbana da cidade do Rio de Janeiro, mostrando que o efeito civilizatório das cidades também está presente através do edifício teatral.

O Teatro de Manoel Luiz, depois Teatro Régio, primeira Casa de Ópera oficial do Rio de Janeiro, apesar de sua arquitetura incipiente, prenuncia o movimento cultural que está por vir numa cidade elevada à categoria de capital de um reino europeu nas Américas, de onde traz seus modelos culturais. O que aqui vinha sendo formulado, na música, nas artes e na arquitetura, tinha algo de original e iniciador da cultura brasileira. Se a vinda da corte para o Brasil e a promoção a reino, bem como a posterior vinda da Missão Francesa, nos levam a um caminho cada vez mais internacional, principalmente com o neoclassicismo, esse momento final do século XVIII e inicial do XIX talvez tenha sido aquele em que a colônia, antes de todas as amarras culturais serem transpostas para cá, se encontrou mais livre, encarnando o espírito desse século XVIII a sua maneira, com uma série de peculiaridades locais. 


\section{Referências}

ALVES, J. J. B. F. O Magnífico Aparato: Formas da Festa ao Serviço da Família Real no Século XVIII. Separata da Revista de História, Vol. XII. Porto: Centro de História da Universidade do Porto, 1993.

AYRES DE ANDRADE. Francisco Manuel da Silva e Seu Tempo, 1808-1865: Uma fase do passado musical do Rio de Janeiro à luz de novos documentos, v. 1. Rio de Janeiro: Edições Tempo Brasileiro, 1967.

BARROW, J. A Voyage to Cochinchina in the years of 1792 and 1793... London: 1806.

BOUGAINVILLE, L. A. Voyage autour du monde, sur la fragate La Bourdeuse... 1766/1769. Paris: Fabre, Feste et Ce, Editeurs, 1771.

BRESCIA, R.de M. M. O. C'est là que I'on joue la comédie: les Casas da Ópera en Amérique Portugaise (1719-1819). Tese de doutorado em História Moderna e Contemporânea e Ciências Musicais da Universidade Paris IV e da Universidade Nova de Lisboa, 2010.

CAVALCANTI, N. O Rio de Janeiro setecentista: a vida e a construção da cidade da invasão francesa até a chegada da Corte. Rio de Janeiro: Jorge Zahar Ed., 2004.

COLLCHETE, A. Praça XV: projetos de espaço público. Rio de Janeiro: 7Letras, 2008.

COUTY, D.; REY, A. Le Théâtre. Paris: Ed. Bordas, 1995

CRULS, G. Aparência do Rio de Janeiro. Coleção Rio 4 Séculos, Vol. 1 e 2. $3^{\circ}$ ed.. Rio de Janeiro: Livraria José Olympio Editora, 1965.

CUNHA, L. da F. F. (Org.) Álbum cartográfico do Rio de Janeiro (Séculos XVIII e XIX). Rio de Janeiro: Edição do MEC, Biblioteca Nacional, 1971.

DIAS, J. da S. Teatros do Rio: do Século XVIII ao Século XX. Rio de Janeiro: FUNARTE, 2012. 
FAgerlande, S. M. R. O Teatro no Rio de Janeiro do Século XVIII. Rio de Janeiro: Monografia final do Curso de Especialização em História da Arte e Arquitetura no Brasil, PUC RJ, 1998.

FAGERLANDE, S. M. R. O Teatro no Rio de Janeiro do Século XVIII - A Casa de Ópera no Largo do Paço In: 200 Anos da Chegada da Família Real Portuguesa ao Brasil: da Abertura dos Portos às Nações Amigas e seus Reflexos na Arquitetura e no Espaço Brasileiro. 1 ed. Rio de Janeiro: Coleção Proarq FAU UFRJ, 2007, v.1, p. 93-112.

FAGERLANDE, S. M. R. Real Teatro São João: um novo modelo teatral na corte do Rio de Janeiro. In: 200 Anos da Chegada da Família Real Portuguesa ao Brasil: da Abertura dos Portos às Nações Amigas e seus Reflexos na Arquitetura e no Espaço Brasileiro. 1 ed. Rio de Janeiro: Coleção Proarq FAU UFRJ, 2007, v.1, p. 113-129.

FERREZ, G. O Paço da cidade do Rio de Janeiro. Rio de Janeiro: Fundação Nacional PróMemória, 1985.

FLEUISS, M. O Teatro no Brasil, sua evolução. In Dicionário Histórico, Geográfico e Etnográfico do Brasil - I vol. parte 3, Rio de Janeiro: Imprensa Nacional, 1922.

FRANÇA, J. A. R. Lisboa Pombalina e o Iluminismo. Lisboa: Livros Horizonte, 1965.

LAVRADIO, J. de A. Vice-Reinado de D. Luiz D'Almeida Portugal. São Paulo: Companhia Editora Nacional, 1942, p.22 a 39.

LAVRADIO, Mq. do. Cartas do Rio de Janeiro: 1769 - 1776. SEEC, Dep. de Cultura. Rio de Janeiro, 1978.

LIMA, E. F. W. Arquitetura do espetáculo: teatros e cinemas na formação da Praça Tiradentes e Cinelândia. Rio de Janeiro: Editora UFRJ, 2000. 
LUCCOCK, J. Notas sobre o Rio de Janeiro e partes meridionais do Brasil, tomadas durante uma estada de dez anos neste país, de 1808 a 1818 . São Paulo: Livraria Martins, 1942.

LUIS EDMUNDO. O Rio de Janeiro no tempo dos vice-reis. In Revista do IHGB. vol 163, tomo 109. Rio de Janeiro: Imprensa Nacional, 1932.

MARINHO, H. O Theatro brasileiro (alguns apontamentos para a sua história). Paris: H Garnier, 1904, p.14 a 22.

MATTOS, C. P. de. José Maurício Nunes Garcia - Biografia. Min. da Cultura, Fund. Biblioteca Nacional, Departamento Nacional do Livro. Rio de Janeiro, 1997.

MENDONÇA, C. História do theatro brasileiro - vol 1. Rio de Janeiro: Mendonça, Machado \& Cia, 1926, p.75 a 173.

MONTEIRO DE CARVALHO, A. M. F. Mestre Valentim. São Paulo: Cosac \$ Naif Edições, 1999.

MORAIS, A. J. de M. O Theatro de Manoel Luiz. In Arquivo do Distrito Federal, Volume 4, Rio de Janeiro: 1897.

MORAND, P. Paris. Paris: La Bibliothèque des Arts, 1970.

NERY, R. V.; CASTRO, P. F. de. História da Música. Coleção Sínteses da Cultura Portuguesa. Lisboa: Imprensa Nacional- Casa da Moeda, 1991.

PAIXÃO, M. da. O Theatro no Brasil. Rio de Janeiro: 1936.

RUY, A. História do Teatro na Bahia - Séculos XVI - XX. Salvador: Publicações da Univ. da Bahia, 1959.

SANTOS, L. G. Memórias para servir à história do Reino do Brasil. Vol I, Rio de Janeiro: Zélio Valverde, 1943.

(c) Urbana: Rev. Eletrônica Cent. Interdiscip. Estud. Cid. 
SILVA, L. História do teatro brasileiro. Rio de Janeiro: Serviço Gráfico do Min. da Educação e Saúde, 1938.

SISSON, R. E. F. Espaço e poder: os três centros de poder do Reio de Janeiro e a chegada da Corte Portuguesa. Rio de Janeiro: Arco, 2008.

SOUSA, J. G. de. O Teatro no Brasil. Rio de Janeiro: INL, 1960.

STAROBINSKI, J. L'Invention de la Liberté: 1700-1789. Genebra: Skira, 1994.

STAUTON, G. An authentic account of an embassy from the king of Great Britain to the Emperor of China. Vol I. London: 1798.

VERSIANI, C. O teatro no cotidiano das Minas setecentistas. In Revista do IFAC, $\mathrm{n}$ o 3 . Ouro Preto: UFOP, 1996, p.66 a 72.

VIEIRA FAZENDA, J. Antiqualhas e memórias do Rio de Janeiro. Tomo 89, Vol.146. Rio de Janeiro: 1921.

(c) Urbana: Rev. Eletrônica Cent. Interdiscip. Estud. Cid. Campinas, SP V.10, n.1 [18] p.104-130 jan./mai. 2018 